
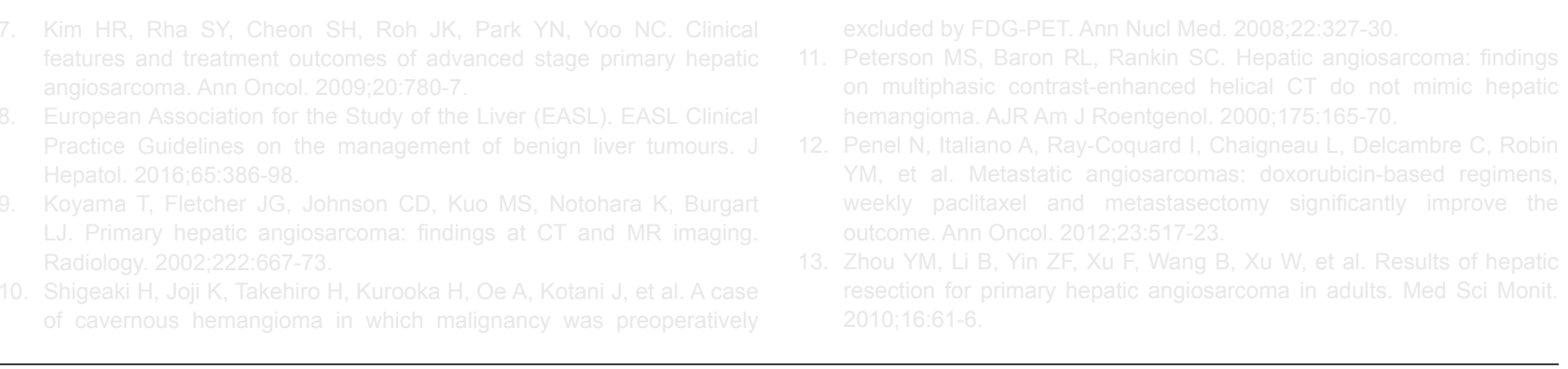

\title{
Methemoglobinemia After Paracetamol Ingestion: A Case Report
}

\section{Metemoglobinemia Após Ingestão de Paracetamol: Um Caso Clínico}

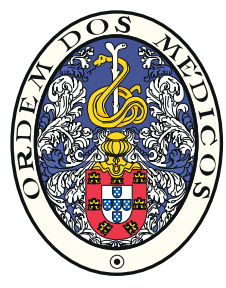

\author{
Catarina QUEIRÓS* $\rrbracket^{1}$, Pedro SALVADOR*2, Ana VENTURA ${ }^{3}$, Daniela LOPES ${ }^{3}$ \\ Acta Med Port 2017 Oct;30(10):753-756 - https://doi.org/10.20344/amp.8722
}

\begin{abstract}
Methemoglobinemia is a potentially fatal condition, mainly acquired after intoxication by certain drugs. To this date, only three cases associated with paracetamol have been reported. This case report describes a patient with autosomal dominant polycystic kidney disease undergoing hemodialysis who was self-medicated with acetaminophen for seven days (at a daily dose of $3 \mathrm{~g}$ ); the patient went to the hospital after noticing the appearance of a diffuse brownish skin tone, without other symptoms. Arterial blood analysis revealed an increase in methemoglobin levels, with biochemistry showing an increase in total bilirubin and alanine aminotransferase. Paracetamol was discontinued and on reassessment nine days after the onset of symptoms the patient had a clear improvement in her skin color, with normalization of methemoglobin levels.
\end{abstract}

Keywords: Acetaminophen/adverse effects; Methemoglobinemia

\section{RESUMO}

A metemoglobinemia é uma condição potencialmente fatal, maioritariamente adquirida após intoxicação por determinados fármacos; até à data estão relatados apenas três casos associados à toma de paracetamol. Este caso clínico descreve uma doente com doença renal poliquística autossómica dominante, sob hemodiálise, que se automedicou com paracetamol durante sete dias (numa dose diária de $3 \mathrm{~g}$ ); a doente recorreu ao hospital após ter notado o aparecimento de uma tonalidade cutânea difusamente acastanhada, sem outros sintomas. A análise de sangue arterial revelou aumento da metemoglobina, tendo a bioquímica apresentado um aumento da bilirrubina total e da aminotransferase da alanina. A toma de paracetamol foi suspensa, e na reavaliação nove dias após o início dos sintomas a doente apresentava uma clara melhoria da cor da pele, com normalização dos valores de metemoglobina.

Palavras-chave: Acetaminofeno/efeitos adversos; Metemoglobinemia

\section{INTRODUCTION}

Methemoglobin refers to hemoglobin with its iron in the oxidized state, which means it cannot reversibly bind oxygen. The normal range of methemoglobin is $0 \%-1 \%$ of the total hemoglobin level ${ }^{1}$ with any increase above this value being called methemoglobinemia.

The vast majority of methemoglobinemias are acquired, ${ }^{2}$ usually resulting from excessive doses of drugs or other substances. Among these, the most frequently associated are dapsone, local anesthetics, sulfonamides, nitrites and aniline or its derivatives.

Paracetamol is currently the only aniline-derivate analgesic still marketed in Portugal. The most common consequences of paracetamol intoxication are well described including: gastrointestinal symptoms and hepatotoxicity; acute kidney injury; acute myocardial necrosis; pericarditis and hypoglycemia. ${ }^{3}$ Here we report a case of methemoglobinemia resulting from paracetamol ingestion, a rare but potentially serious complication of this drug.

\section{CLINICAL CASE}

Our patient was a 78-year-old woman with a history of autosomal dominant polycystic kidney disease on hemodialysis for 30 months as well as a mild cognitive impairment due to vascular dementia. She was chronically medicated with acetylsalicylic acid, calcium acetate/ magnesium carbonate, quetiapine and hydroxyzine.

Our patient came to the hospital due to the appearance

\footnotetext{
${ }^{*}$ Co-primeiros autores.

1. Serviço de Dermatologia. Hospital de Santa Maria. Centro Hospitalar Lisboa Norte. Lisboa. Portugal.

2. Serviço de Medicina Interna. Centro Hospitalar de Vila Nova de Gaia-Espinho. Vila Nova de Gaia. Portugal.

3. Serviço de Nefrologia. Centro Hospitalar de Vila Nova de Gaia-Espinho. Vila Nova de Gaia. Portugal.

$\triangle$ Autor correspondente: Catarina Queirós. catarina.squeiros@gmail.com

Recebido: 22 de janeiro de 2017 - Aceite: 27 de março de 2017 | Copyright @ Ordem dos Médicos 2017
} 
of a brownish skin tone since that morning, with no itching or other complaints (Fig. 1). She had been on hemodialysis the previous day, after which she took $1 \mathrm{~g}$ of oral paracetamol due to a slight elevation of her axillary temperature. She denied other symptoms, as well as intake of other drugs or substances apart from paracetamol $1 \mathrm{~g}$ three times daily for the previous seven days, due to osteoarticular complaints.

Upon physical examination she presented a diffuse brownish skin tone, with no other relevant alterations. Arterial blood gas analysis showed an increase in the percent of methemoglobin (3.3\%). The complete blood count revealed an already known normochromic normocytic anemia (hemoglobin $11.2 \mathrm{~g} / \mathrm{dL}$ ), without leukocytosis or other changes. The peripheral blood biochemistry was successively impossible to analyze due to repeated hemolysis of the four samples collected. The fifth sample allowed some results, among which were an increase in total bilirubin $(1.62 \mathrm{mg} / \mathrm{dL})$ and alanine aminotransferase (62 U/L).

The diagnosis of paracetamol-related methemoglobinemia was suspected, and the patient immediately stopped taking this drug, staying under observation. Two days later the skin color was bluish and the arterial blood gas analysis showed a discrete decrease in the percent of methemoglobin, which was now $2.9 \%$. The analytical
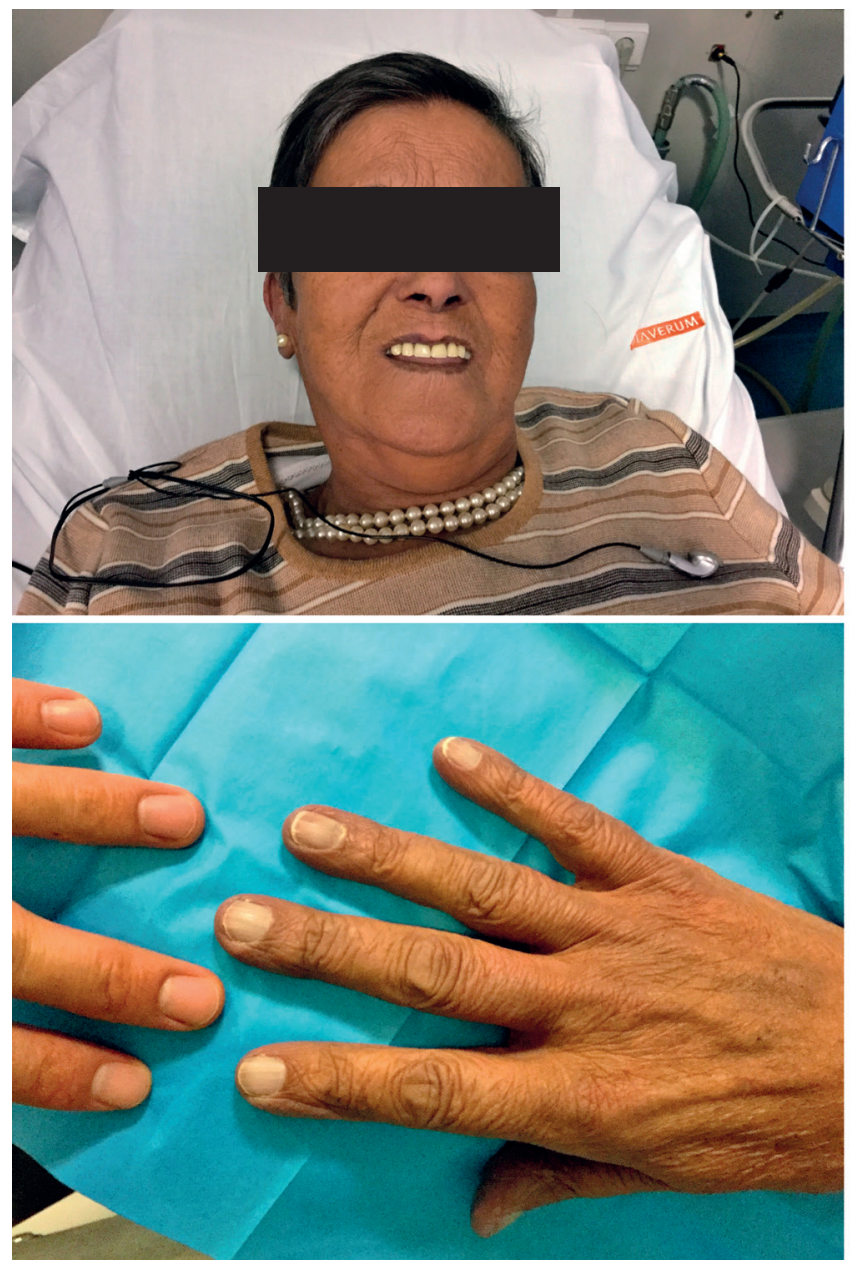

Figure 1 - Patient presenting a brownish skin tone study revealed again an increase of bilirubin as well as of hepatic cytolysis enzymes. These findings supported the hypothesis of a paracetamol-related methemoglobinemia; the patient was discharged and advised to avoid this drug.

Nine days after the onset of symptoms the patient returned for reexamination. She reported a clear improvement of her skin color (Fig. 2). The analytical study did not show any significant changes; the arterial blood gas analysis showed a normalization of the percent of methemoglobin $(0.6 \%)$.

\section{DISCUSSION}

Methemoglobin refers to hemoglobin with its iron in the ferric or oxidized state, which means that, contrary to the functional hemoglobin (with its iron in the ferrous or reduced state), it cannot reversibly bind oxygen. The normal range of methemoglobin is $0 \%-1 \%$ of the total hemoglobin level, ${ }^{1}$ with any increase above this value being called methemoglobinemia.

Patients with acutely increased concentrations of methemoglobin have a functional anemia, as the amount of functional hemoglobin is less than the measured level of total hemoglobin. This results in tissue hypoxia by two mechanisms: first, methemoglobin is unable to bind and deliver oxygen; second, the remaining reduced hemoglobin has a higher affinity for oxygen, which means there is a left

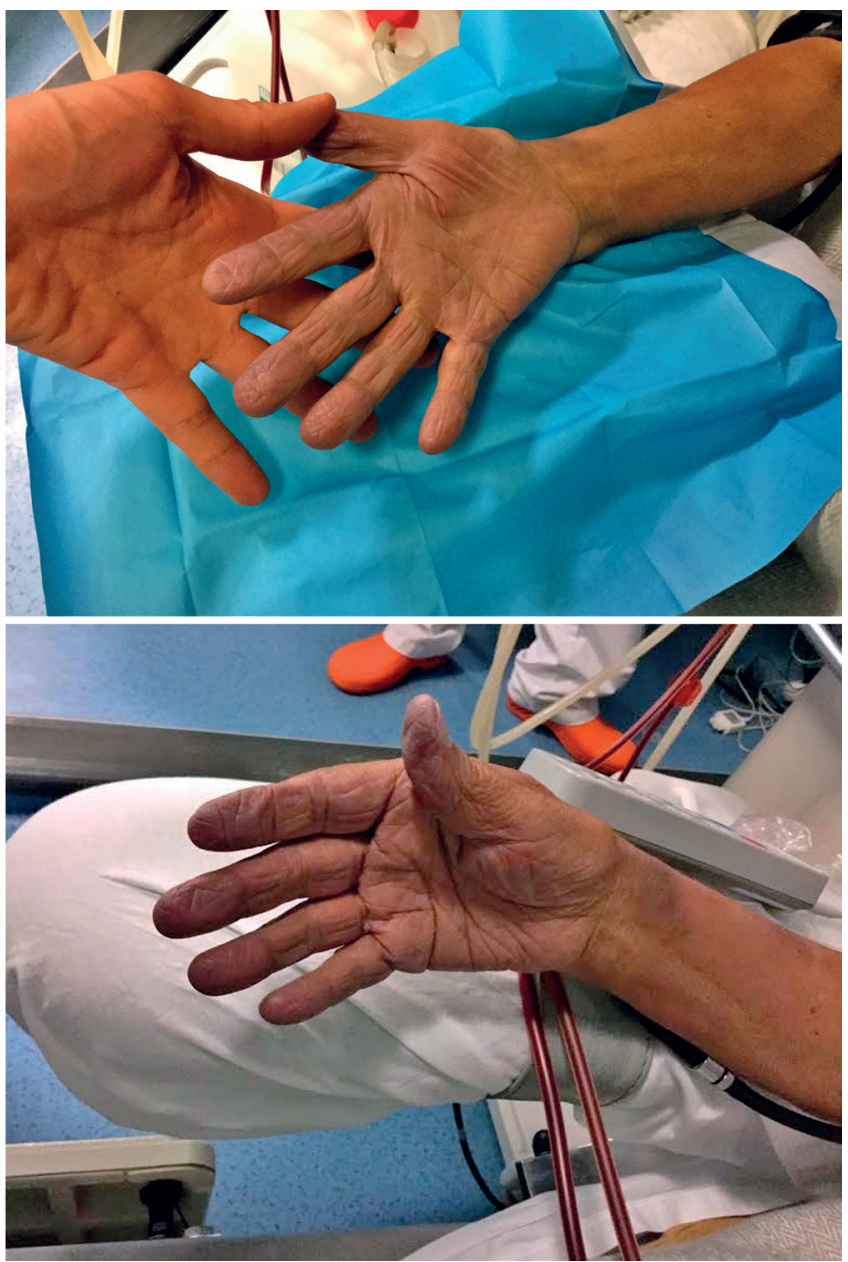




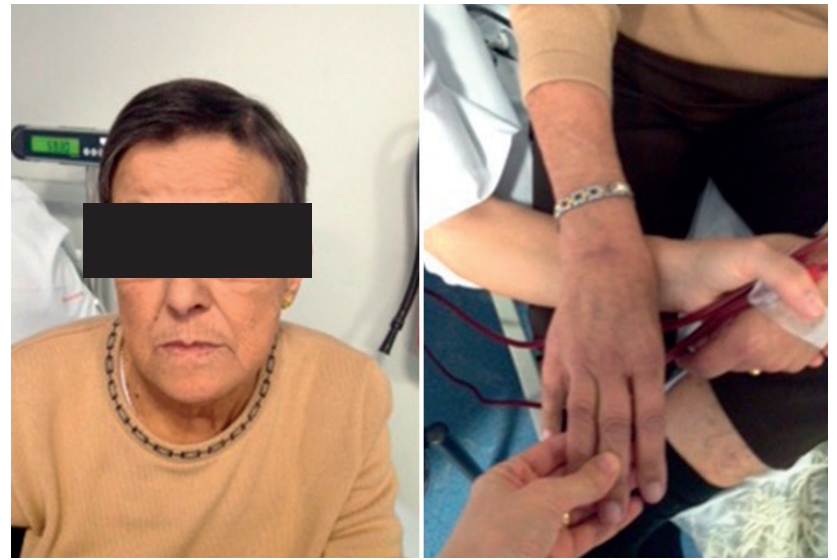

Figure 2 - After recovering from the methemogobinemia, the patient returns to her normal skin tone

shift in the oxygen-hemoglobin dissociation curve. ${ }^{4}$

There are two types of methemoglobinemia: congenital, where the enzymatic reduction of methemoglobin back to functional hemoglobin is diminished and acquired, in which ingestion of specific drugs or oxidants cause an increase in the production of methemoglobin. The vast majority of methemoglobinemias are acquired, ${ }^{2}$ resulting from excessive doses of substances such as dapsone, local anesthetics, sulfonamides, nitrites and aniline or its derivatives.

In acquired methemoglobinemias, there is impairment in oxygen delivery to tissues that does not allow sufficient time for the development of compensatory mechanisms. Early manifestations of this condition include an alteration in skin color, which can appear pale, gray or blue; other symptoms such as lightheadedness, headache, tachycardia and dyspnea usually do not become apparent before methemoglobin levels of $20 \%$ to $30 \%$ of the total hemoglobin. In the presence of more than $50 \%$ of methemoglobin, severe symptoms of hypoxia appear. ${ }^{2,5}$ Levels above $70 \%$ are usually fatal.

Treatment of patients with acquired methemoglobinemia will vary according to the percentage of methemoglobin present; if the level of methemoglobin is less than $20 \%$, the patient is usually asymptomatic and the only therapy needed is discontinuation of the offending agent. On the other side, if the patient is symptomatic or in the event of a methemoglobin level of more than $20 \%$, it may be necessary to manage the patient in an intensive care unit and use specific therapies such as methylene blue.,

Aniline emerged as an analgesic substance in the late $19^{\text {th }}$ century, ${ }^{8}$ with acetanilide being the first aniline derivative with analgesic and antipyretic properties introduced in the market. Its high toxicity, mainly due to the production of methemoglobin, lead to the search and development of other less toxic aniline derivatives, such as phenacetine and paracetamol. ${ }^{9}$ Paracetamol is currently the only aniline derivative still marketed in Portugal.

In our patient, the only manifestation of the underlying condition was the discoloration of the skin. She did not present any other symptom, which was not surprising as she had only a slight elevation of the methemoglobin. Our patient also denied having ingested any kind of substances or drugs apart from paracetamol, which she had been taking on regular basis for the last seven days, about $3 \mathrm{~g}$ each day.

The most common consequences of paracetamol intoxication are well described, and include gastrointestinal symptoms and hepatotoxicity; acute kidney injury, myocardial necrosis, pericarditis and hypoglycemia have also been reported. ${ }^{3}$ Methemoglobinemia secondary to paracetamol is not common, with only a few cases reported in the literature. The first report dates to 1968, and describes a woman who developed methemoglobinemia after taking therapeutic doses of paracetamol for post-partum pain. ${ }^{10}$ Later, in 2000 , a case of methemoglobinemia induced by combined use of sodium nitrate and paracetamol was described in Japan. ${ }^{11}$ More recently, Kanji HD et al reported the occurrence of coma, metabolic acidosis, and methemoglobinemia in a patient with paracetamol toxicity. ${ }^{4}$

The reason why paracetamol can lead to methemoglobinemia is not clear; however, four points in our case suggests that the culprit may be an active metabolite related to paracetamol (and hence to aniline): first, aniline related methemoglobinemia seems to be associated with an oxidant active metabolite, which appears to be phenylhydroxylamine ${ }^{12}$; second, it is known that aniline exposure can lead to hemolysis, ${ }^{13}$ and in our patient the blood samples for biochemical analysis were repeatedly hemolysed; third, phenylhydroxylamine intoxication is associated with hemolysis in individuals with G6PD deficiency ${ }^{14}$ and it has been reported that a large proportion of patients on hemodialysis show a functional G6PD deficiency ${ }^{15}$; and finally, our patient improved spontaneously after the suspension of paracetamol.

\section{CONFLICTS OF INTEREST}

The authors have no conflicts of interest to disclose.

\section{DATA CONFIDENTIALITY}

Informed consent was duly obtained from the patient.

\section{FUNDING SOURCES}

No grants or any other type of support was received for this work.

\section{REFERENCES}

1. Longo DL, Fauci AS, Kasper DL, Hauser SL, Jameson J, Loscalzo $\mathrm{J}$, et al. Harrison's Principles of Internal Medicine. $18^{\text {th }}$ ed. New York: McGraw-Hill; 2012.

2. Coleman MD, Coleman NA. Drug-induced methaemoglobinaemia Treatment issues. Drug Saf. 1996;14:394-405.

3. Drug Information 2013. American Society of Health-System Pharmacists. 4. Kanji HD, Mithani S, Boucher P, Dias VC, Yarema MC. Coma, metabolic acidosis, and methemoglobinemia in a patient with acetaminophen toxicity. J Popul Ther Clin Pharmacol. 2013;20:e207-11.

5. Cortazzo JA, Lichtman AD. Methemoglobinemia: a review and 
recommendations for management. J Cardiothorac Vasc Anesth. 2014;28:1043-7.

6. D'sa SR, Victor P, Jagannati M, Sudarsan TI, Carey RA, Peter JV. Severe methemoglobinemia due to ingestion of toxicants. Clin Toxicol. 2014;52:897-900

7. Rino PB, Scolnik D, Fustinana A, Mitelpunkt A, Glatstein M. Ascorbic acid for the treatment of methemoglobinemia: the experience of a large tertiary care pediatric hospital. Am J Ther. 2014;21:240-3.

8. Wilcox RW. The treatment of influenza in adults. Med News. 1900;15:931-2

9. Goodman LS, Joel G, Limbird LE, Gilman AG. Goodman \& Gilman's the pharmacological basis of therapeutics. $10^{\text {th }}$ ed. New York: McGraw-Hill; 2001.

10. MacLean D RP, Bain S. Methaemoglobinaemia and paracetamol. BMJ. $1968 ; 4: 390$
11. Kobayashi T, Kawabata M, Tanaka S, Maehara M, Mishima A, Murase T. Methemoglobinemia induced by combined use of sodium nitrate and acetoaminophen. Intern Med. 2000;39:860.

12. Ravi Kumar Y, Manthappa, Kumar P, Prasad M, Radhika A, Edara AC. Occupational inhalation of aniline fumes induced methemoglobinemea and hemolytic anemia precipitated days later. Indian J Occup Environ Med. 2014;18:95-6.

13. BASF Chemical Emergency Medical Guidelines - Aniline $(\mathrm{C} 6 \mathrm{H} 5 \mathrm{NH} 2)$ - Information and recommendations for paramedics and doctors at the site. Florham Park: BASF - The Chemical Company; 2012.

14. Hazardous Substances Data Bank: N-phenylhydroxylamine, toxicology data network. Bethesda: National Library of Medicine; 2003.

15. Ali EW, Ahmed EE. The role of erythrocyte enzyme glucose-6-phosphate dehydrogenase (G6PD) deficiency in the pathogenesis of anemia in patients on hemodialysis. Saudi J Kidney Dis Transpl. 2013;24:1153-6. 